\title{
Approach to Dynamic Assembling of Individualized Learning Paths
}

\author{
Vladimir LUBCHAK, Olena KUPENKO, Borys KUZIKOV \\ Sumy State University \\ 2 Rimsky-Korsakov str., 40007 Sumy, Ukraine \\ e-mail: lub@sumdu.edu.ua,lena@dl.sumdu.edu.ua,b.kuzikov@dl.sumdu.edu.ua
}

Received: May 2012

\begin{abstract}
E-learning students are generally heterogeneous and have different capabilities knowledge base and needs. The aim of the Sumy State University (SSU) e-learning system project is to cater to these individual needs by assembling individual learning path. This paper shows current situation with e-learning in Ukraine, state-of-art of development of the adaptive e-learning systems and shows results of SSU research in this area. Nowadays the received solutions are different from the known analogues considering an expanded set of information about the features of a particular student's learning activities (19 indicators are analysed, including indicators of progress such as the level of knowledge and student individual features). The corresponding software solutions are being tested in the SSU e-learning environment.
\end{abstract}

Keywords: e-learning, e-learning platform, adaptive e-learning, individualized learning path, learning path assembling.

\section{Introduction}

Modern higher education is designed to prepare specialists to solve problems in continuously changing environment. At the same time, students have different capabilities and knowledge base. This fact determines the need for different content, forms, and methods of presentation of training materials. There is a shift from building courses in a way "one size fits all" to courses with individual learning path.

The implementation of individual learning path suggests that there are many options for training materials for current training purposes. For selection of educational materials for the course is advisable to use an open repository of educational resources.

Nowadays there are enough international open educational resources in World Wide Web. For example, the global community Open Education Resources (OER; Pegler, 2012) provides free access to more than 30,000 categorized study objects, flexible means for their filtering and searching (OERcommons.org). In combination with the authored materials, these and other open educational resources allow each teacher to provide quality educational services for every student.

In the Ukrainian segment of Internet open access and exchange of materials for educational purposes, according to international experts, is rather a single case than 
a trend (UNESCO, 2010). Sumy State University (SSU) takes active role in the development of the national component of open educational resources. Educational materials for more than 200 one- and two-semester courses in 11 specializations have been developed (among developed - electronic books, videos, java-and flash-simulators) (HI-Tech in SSU). International projects on the problems of e-learning were carried out (Vasiljev and Lubchak, 2008; Lubchak and et al., 2010). In 2011 the University Academic Council adopted the "The development concepts of a common educational e-learning environment at SSU". The common educational e-learning environment is being developed as a dynamic adaptive control system of blended learning.

In the past few years high attention in SSU was paid to increasing of the quality of existing e-learning resources. The work on the actualization of the content of courses, implementation of advanced methods of the educational process intensification continues. Among the main objectives of this work one can distinguish the following:

- inclusion or adaptation of learning objects from external sources to improve the quality of the courses; training teachers the basics of using such materials considering licensing and other restrictions;

- providing open access to educational resources, including interactive ones; creation of the repository of authored scientific and learning resources;

- development of tools for choosing of an optimal set of learning materials for a particular student and for the construction of individual learning path, with the condition of guaranteed basic knowledge acquirement;

It should be mentioned that regardless of the source of learning objects special tools of building and managing of the learning path for each student are required. Development of such tools requires special pedagogical approaches and software solutions. This is the subject of this article.

\section{Models of the Creation of Individual Learning Path in Terms of Large Volumes of Learning Materials}

\subsection{Search-Engines and Hypermedia Web}

The development of adaptive tools, which allow to dynamically build an individual educational path is complex and expensive. Widespread for educational purposes are therefore universal ways of organizing an individualized instruction based on the potential of hypermedia and search engines. These tools provide the student with the full freedom of navigation, but also carry some risks as to the achievement of learning objectives (Berghel, 1997, Hiroyuki et al., 2002).

Let's emphasize the main disadvantage of systems based on the freedom of navigation and search engines. The quality of search results depends on the accuracy of the search request. It is known that the right question already contains part of the answer. The quality of the search depends on whether the student understands what he is looking for. So he must have a mental model of the course - the notion of concepts and their place 
in the studied knowledge area. Without special tools of management of an individual learning path a student can aimlessly wander around the web of relationships between learning objects, open the Terra Nova of interesting information, which may be in no way connected with the current learning objectives.

\subsection{Search Engines on Object within Domain Space}

It should be said that in the development of digital educational resources, there are two extremes: (1) providing complete freedom of navigation in educational internet resources, (2) setting a single unchangeable path for all students (the practice of programmed instruction in the 1950-1960-ies). One way of resolving the contradiction between the two extremes is the æustom æourse system developed by IBM (Farrel, et al., 2003).

This software allows to build arbitrary topic courses with limited duration in response to queries made by users. Learning objects for the Custom Course are extracted from the how-to books on IBM products. The main metadata of the objects - title, subject, duration, keywords - are automatically extracted from source materials and presented according to the IEEE Learning Object Metadata (LOM) standard. The logical connection is established not between the objects, but keywords that are used in them.

The system uses learning objects which require 2-15 minutes for their studying. The total length of the course is less than 2 hours. Thus, the course can be studied in a single work session. Utilization of past student experience occurs in "manual mode": student can manually exclude certain objects from the course before the start of its studying. Despite the positive sides, a small length of the course limits the use of the Custom Course for higher education, where the duration of courses is usually much longer. If we try to increase the length of the course, we need to implement controls for completeness and correctness of received knowledge, correction algorithms and dynamic course adjustment based on individual achievements of a student.

\subsection{Systems Built on Multi-Level Domain Model}

The system of creation and management of individual learning paths must always be ready to offer a number of learning objects to the user, which, on the one hand, respond to his individual needs and preferences, and, on the other - to the learning objectives. So, such systems must have mechanisms for ranking, filtering and selection of learning objects.

Such mechanisms can be implemented when there are multiple levels of information about the objects, with which the system operates. Thus, in the form of ontologies of different levels, following may be represented: the amount of knowledge that a student should receive, the relationship between the concepts in the subject area, the relationship between concepts and objects etc. By going through the levels of ontologies (from general to particular), the system specifies which objects are most suitable in given situation. This model of organization of educational material is put into practice in the system of lifelong learning FreshKnowledge. Key concepts for this model are in Gagarin and Tytenko (2007): 
- Complex Content Model (CCM) is responsible for formalization of structure and content of all educational materials. This model is based on two dependent models. Concept-Thesis Model (CTM) formalizes educational text by its semantic and didactic elements retrieving. Tree-Net Model of educational content organization (TNM) formalizes semantic and didactic structure and relationships of educational materials. It is used on two levels of knowledge: inside of the course and on the level of global set of courses.

- Professional Competencies Model (PCM) - models knowledge about specialties, professions and positions. PCM focuses on professions and positions that are in popular demand on the labour market.

- Educational Query Model (EQM) is a set of methods for realization of personal user demand to the system to get educational services.

Based on the user model and on the model of professional competence FreshKnowledge selects a set of learning objects, which you need to study to get specific qualifications (knowledge, skills or attitudes). The knowledge obtained by a student is controlled through the tests. Tests are automatically generated using the CTM. In the model of Tree-Net the connection is established not only between the concepts, but also between learning objects. The student operates simultaneously with three groups of links: (1) links between objects (within common topic group), (2) links to object with similar topic, (3) links to resources that may interest the student (based on a list of concepts that should be studied). The student is presented a large number of links, there is no clear criteria in what direction he should continue his education. Thus the shortcomings of systems with free navigation in the space of learning objects are coming up. That is, the value of providing intelligent referencing is decreasing.

\subsection{Collaborative Learning}

We have looked at the approaches to the creation of individual learning paths. As a result of taking an individual learning path, we must ensure that the student receives a basic level of knowledge of the course.

In this analysis we left behind the scenes one important component - the interaction between users. It is important to remember that learning is a process of transfer not only of knowledge but also of skills. Experts (Kureichik et al., 2008) consider that one of the main components of competency for many specialists today is skills to work in a group. Typically, such skills are trained by using wiki (the tools of the collective creation of a common resource), forums (user interaction in an asynchronous mode), chat (communication in synchronous mode). Opportunities to participate in such activities should also be considered when building an individual learning path.

A group of students should be viewed not only as a formal union, but as microcommunities with common interests. In this case, the collective data filtering can be used. This approach came from the field of e-commerce - people with similar interests are looking for similar resources. In our case students, by passing through the set of the material in their own way, help other colleagues to build the most effective way. Building a path 
on a graph by a group of interacting agents has been called "ant algorithm" (Jones, 2008) and is a very effective way to work with the networks of linked objects (in our case, with learning resources).

\section{Multi-Level Domain Model with Extended User-Experience Utilization}

The approaches above illustrate the direction of development of the system for creation and management of individual learning paths from simple hypermedia resources with search engines to more complex mechanisms of support of the different types of filtering of the learning objects. In this case two trends can be observed. The first one - the volume of metadata utilization is increasing: search engines look at simple metadata, Custom Course looks into metadata of connected nodes, FreshKnowledge uses the links between nodes, the user model, the professional competence model (PCM). This trend is associated with a desire to harmonize the material provided for the user with his previous knowledge. Another trend is strengthening of the role of feedback in the creation of individual learning paths.

Let's illustrate the process of expanding of the tools that take into account individual characteristics of a student in the form of the graph. The X-axis - the use of feedback when students work with educational objects, the level of adoption of learning objects, analysis of the volume and nature of knowledge acquired by the student while studying the subject. The $Y$ axis - the amount of metadata that should be considered when building an individual path - learning objectives, the objectives of separate courses, the content of existing learning objects, features of their presentation (Fig. 1).

After analyzing these trends, SSU has proposed to introduce a model of a learning management system that uses the concept of individual learning paths based on the following components:

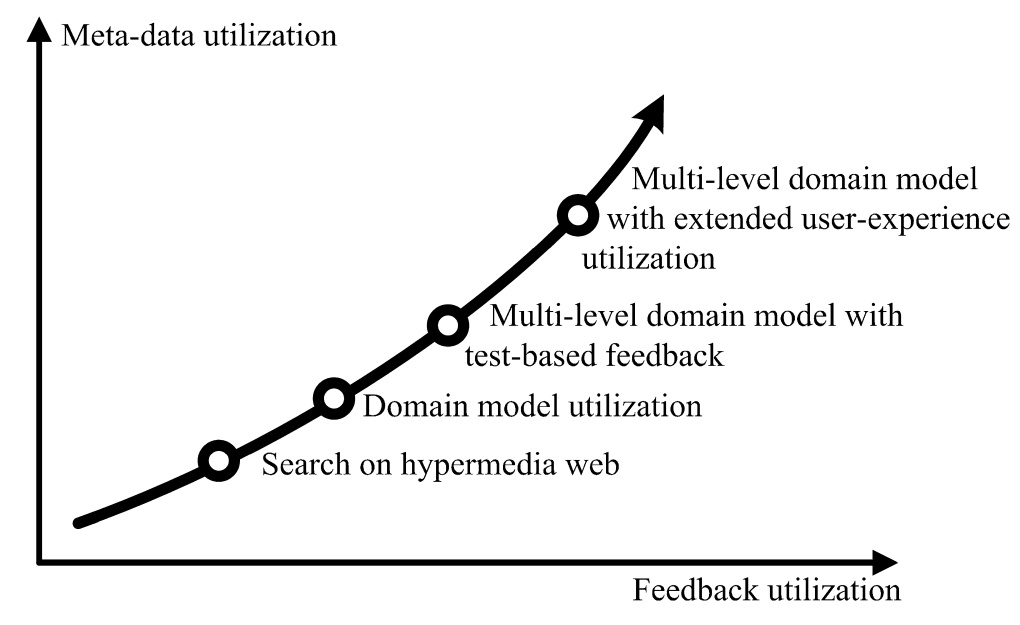

Fig. 1. The use of metadata and feedback in systems with individual learning path. 
- Global ontology of concepts that are present in the learning system. Between the concepts the relation of synonymy can be established. All concepts have their own type and are divided into general scientific, private, and those, which meaning differs from generally accepted within the course. Concepts can relate to knowledge (such concepts we tried to associate with the glossary of the course) and be abstract. Abstract concepts (meta-concepts) describe the necessary skills (e.g., "Upper-Intermediate knowledge of English") or content facilities (e.g., "video"). Thus, the course can be pre-requisites, but now it is not practiced. All concepts, regardless of type, have the same content ranking priority, regardless of type, have the same content ranking priority.

- Knowledge base for the repository of learning objects which contains information about: concepts which are given in objects and concepts necessary for learning this objects. The base is a table with the following columns: <term_id, term role, object_id, object type $>$. In this way atom nodes (learning object), and composite objects (topics, courses, groups of courses etc.) are described.

- The user model is represented by two components. The first part is responsible for the user's knowledge. It contains information about the probability that the concept is fully understood by the user. Information is updated by "layers" in passing the knowledge control session. The model contains a current evaluation of the student's knowledge and history of the accumulation of this knowledge. The second part of the user model provides access to the statistics of using LCMS by user. Now it turns into decision-making system, as described in Section 4.

- To control the completeness and correctness of the studied material at the current stage we use tests. The student testing results become the basis for the modification of the individual learning path. A list of materials is proposed that a student needs to relearn, or to which student can move on. Also, the opportunity to re-take the test is given. This provides the forecast of the probability of success of the test. The forecast is based on the statistical results for the user, and on the test. More details on this mechanism are described by the author of the publication (Kuzikov, 2011). It is planned to implement an analysis of the results of virtual laboratory work and other tasks. The use of other tools of knowledge control (chat rooms, forums, written reports) requires further research.

- For the creation of individual learning path a two-level decision support system is used. In the first stage, based on the result of knowledge control and analysis of past performance the recommended strategy of behavior is determined. In the second stage, we modify individual learning path based on the chosen strategy of behavior and on level of mastering of determined concepts. This component is described in detail in Kuzikov (2011) and the Section 4 of this article.

We use relational database to store all this models. Correspondence between the learning objects and concepts are constructed using the program for morphological text analysis - MyStem (for Russian language) and Stemka (for Ukrainian language). More details on this solution are shown in Lubchack et al. (2010).

Thus, each student is given an opportunity to get the material in the form and content most appropriate for him. The principal difference from the models proposed above is the 
consideration of additional information to construct an individual learning path. Nowadays, 19 indicators are analysed, which relate both to the current session of knowledge control and to the previous learning history. The following parameters are analyzed:

1. Test parameters:

- the percentage of successful passing of the test (for everyone);

- the average complexity of knowledge testing.

2. User parameters:

- the probability that the user will pass the test successfully if he tries to pass it now (with the current results and without them);

- percentage of knowledge on the course;

- the user role.

3. Parameters of test session:

- duration of test session;

- the average duration of the answers;

- the percentage of correct answers;

- the number of test session in the current session of work with LCMS;

- were the lecture materials studied during the current session, subsession of work with LCMS?

- duration of a current session, sub session of work with LCMS.

4. Knowledge base parameters:

- how many nodes for further study may be suggested?

5. Other parameters.

Besides, together with the concepts that define certain knowledge, the system operates with meta-concepts that are associated with particular skills or aptitudes. Examples of such meta-concepts may be the degree of foreign language skills, math learning bias or inclination to use video content for training. Information about how users interact with each other and other people with the learning objects is also considered in construction of an individual learning path (yet we cannot say that we have achieved considerable success in this area).

\section{On-Going and Future Work}

During the preliminary studies, it became clear that not all factors affecting the effectiveness of training can be taken into account using only the information about the content. For example, such factors as the propensity of using audio or video can be tracked by marking the content by the relevant meta-concepts. In this case the preferences of this kind will be automatically taken into account in the content ranking together with other factors. On the other hand, some individual characteristics of students (for example: "the habit of working late at night") depend on the student, but not on the offered to him content.

According to this there has been proposed and implemented a two-level decision making system (DMS). The first level of DMS is responsible for the choice of further training 
strategy and execution of an action related to the chosen strategy (reaction). The second level, if it required by the reaction, selects the desired content based on a model of knowledge and skills of the user.

The research was divided into several stages. In the first stage we make an analysis of the users. On this stage we identified strategies which are used by students after finishing of the knowledge control session (in our case testing). These were: to repeat previous content, to go to the next content, to move to another discipline, to finish the work with the LMS, to try to take the test once again. After that there was created decision making system based on user activity, which helped us to choose the necessary strategy. For the building of the DMS there was used Information-extreme intelectual technology (IEItechnology; Dovbyshet al., 2011). The choice of tools for creating DMS was influenced by the fact that IEI-technology provides mathematical tools to evaluate the effect of input parameters to the criterion of functional efficiency of DMS. It is used by us to find, the optimum in this case, a set of parameters for DMS. The main difficulty with this approach is to analyze the data. Let's call LCMS reaction as 'strategy', and values of all indicators of user activity as 'precedent'. The chosen strategy for current precedent is 'successful' if student passes next knowledge control session. In fact, when we analyse a history of user activity, all precedents can be divided into two categories: (1) A strategy does not bring the desired result for a current precedent, (2) the result of chosen strategy is successful for current precedent, but there is no guarantee that the chosen strategy is optimal. DMS was developed using the modified learning algorithm. Due to DMS, we were able to build individual learning paths based on user behaviour and his knowledge. The experience of using LCMS with this module is described in the first example at Section 5.

When building a DMS, it became clear that the reaction to the same strategy for different user groups may be different. To accommodate this feature, we redesigned the DMS using object-oriented approach. The students were divided into 3 basic groups: e-learning students, full-time students and guests. The implementation of the DMS for each of the groups inherits all the properties of the default DMS, but these properties (reaction to the strategy and the strategy itself) can be redefined. This approach can be referred to the use of multi-core user model (Brusilovsky, 2007). So we got LCMS which can build individual learning paths based on user knowledge and personalized learning strategies. A key feature of implementation is that the precedent is stored only on the lower level of the hierarchy, and these data are provided in both directions (from child to parent and back). Parent object borrows from subsidiaries the most recent data. Child partially borrows data from the parent, if their own is not enough to teach the DMS. Such data exchange on the one hand, allow to build the DMS in low amounts of initial data, adapting to the characteristics of the object as their accumulation. On the other hand the parent object is always operates with the latest data. This allows quick tracking of changes in the students' behaviour.

In fact, this is an intermediate stage and in practice it does not bring anything new: the experimental group for the first phase were the e-learning students. For other basic groups there was realized the possibility of application, but the mechanism of adaptation has not been activated due to the need to develop additional reaction to described strategies. Studies continue on this stage. 
An affiliation of the student to formal group does not guarantee the uniformity of criteria for determining the reaction for the behavioural strategies. In the third stage of the research we decided to implement one's own DMS for every user, which would more accurately choose a suitable strategy. With a lack of input data, they are borrowed from the parent DMS. With the accumulation of input data personal DMS adapts to its user Retraining DMS is going after the accumulation of new data. Nowadays bound for retraining is $5 \%$ of new data. This approach allows updating DMS for new users more frequently without spending resources on users, about which enough data collected. For this stage we are testing the modules source code now.

The system which will be built in the third stage allows adjusting the reaction of DMS on a strategy for each user. However, it is obvious that it is not economically viable. Therefore, in future we plan to add a mechanism of clustering, which would naturally divide users on rather large groups with a similar behaviour. For such relatively large groups, there can developed own reactions on user actions. According to their structure the cluster DMS did not differ from basic DMS and are only the additional level of hierarchy. These steps are illustrated in Fig. 2.

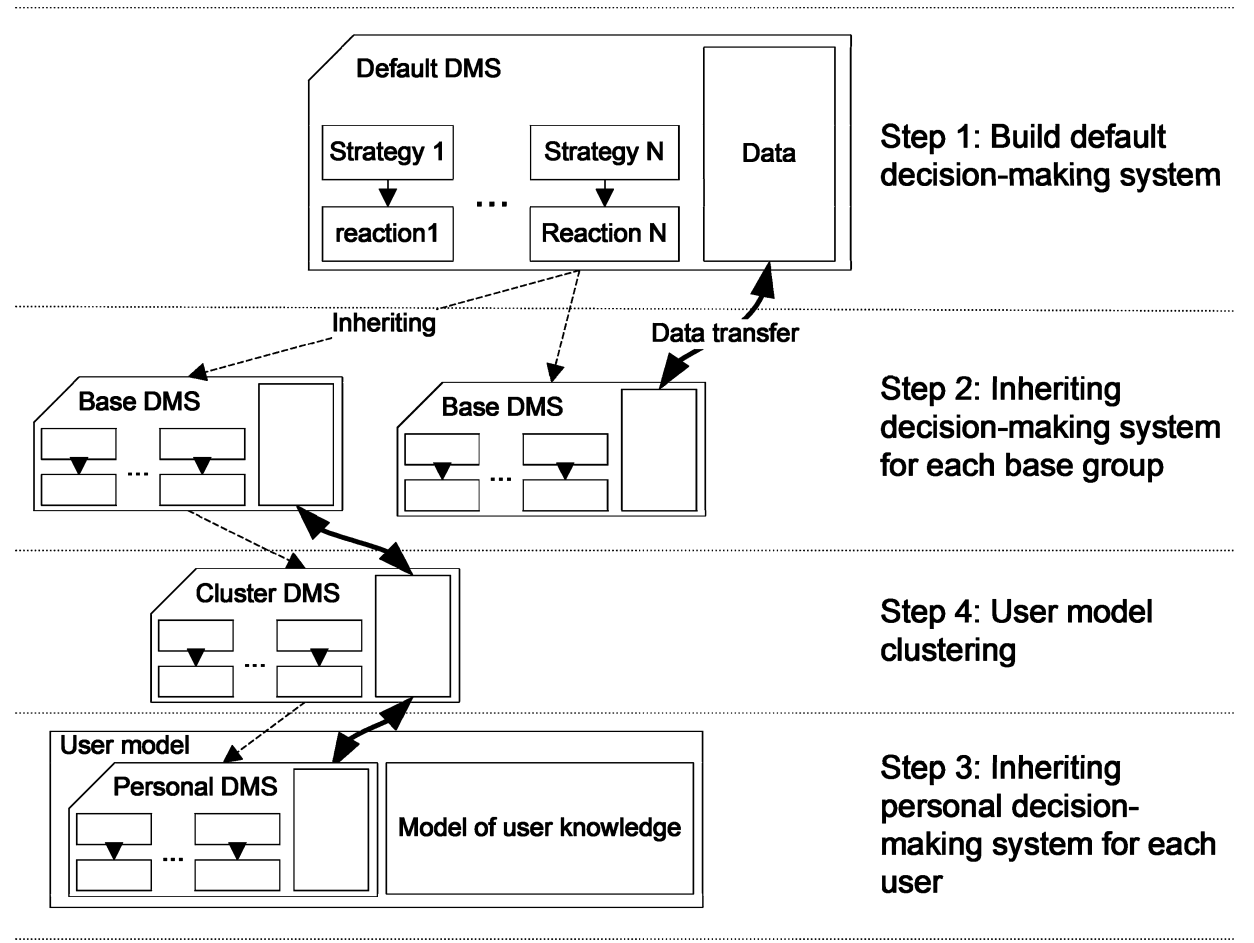

Fig. 2. The scheme of hierarchical of DMS for choosing a LCMS strategy, based on the activity of the student. 


\section{Case Studies of Implementation of Individual Learning Paths at SSU}

In the e-learning system of SSU the presented approaches to the construction of individual learning path are going through the stage of their pilot usage. Here are some examples.

The first example is the course "Theory of algorithms and mathematical logic" for students. Course materials are selected by the author in a way that allows to choose a learning path from the several variants:

- basic course materials, authored by tutor. This materials are fully consistent with the curriculum;

- list of chapters from the book (Cormen et al., 2001) for a deeper understanding of course material;

- English-language materials by Prof. Charles Leiserson, posted on the Open Course Ware MIT (MIT OCW) for students focused on work in international companies;

- understanding of the assessment of the computational complexity of algorithms can be obtained from the selected chapters of Knuth (2005), this material is recommended for students specializing in mathematics;

- repository Codes (GitHub. com, SorceForge.net etc.), specialized forums (StackOverflow.com, AskDev.ru, Habrahabr.ru), as well as source codes in different programming languages for students focused on the practical application of knowledge.

The support module for the construction of an individual path on the basis of test results was tested on 2 academic subjects involving 275 students (10\% of active users of the SSU e-learning system). During the testing of the module the number of students, who have returned to repeating of the basic and supplementary learning materials has increased by $17 \%$ (out of those who passed the test with a satisfactory result). The percentage of rejects to use the support module for separate stages of education was $0.3 \%$ ( 1 rejects), and $1.8 \%$ ( 5 rejects) from the use of support module in general. An opportunity to leave a message to developers was given to each student. In general, a positive response has been received. The poll of students showed the increased motivation for learning.

The second example is a "Latest advances in science and practice" course from the training program for teachers. The idea of this course came in connection with the fact, that representatives of various fields of science, teachers of different courses from other higher education institutions improve their skills at SSU. The second reason this course intersectoral trends in the development of modern science and industry. In the first phase three basic paths were established: (1) modern science, (2) new materials and technologies, (3) entrepreneurship in science, industry, services and education.

The peculiarity of this example compared to the first one (student course "Theory of algorithms and mathematical logic") is to monitor the work with educational objects. Here one should mainly evaluate not the completeness of assimilation of the offered theoretical material (and therefore the final test is not being used), but the subjective "discovery" of new interdisciplinary knowledge by the participant of the training program (we use a feedback questionnaire about the usefulness of the proposed materials, analyze essays and the results of the group work). 
$50 \%$ of teachers made the final works of training programs on the high level. In these works there was presented the integration of personal experience and the new, for a particular teacher content, methods and training aids. In previous cases, the percentage of creative works was lower. Teachers expressed displeasure with the content of training programs. Now the teachers unanimously rated the versions of the material offered to them.

The next stage in teachers training programs is the integration of three existing base paths into a single knowledge base with the ability to "manually" (by the choice of a teacher from the list of proposed content) form an individual path out of the course materials and links to external open resources, the allocation based on the "ant algorithm" of the preferred path for user group of the course. The next future step would be to build multi-level ontology concepts of the course with the establishment of the logical connections.

\section{Conclusion}

Including of learning objects from open sources to the educational process creates new opportunities for teachers for individual approach to each student. However, without special tools for building and management of individual learning paths there is a problem of distracting the students to off-site materials, the loss of focus in the educational activity. The need to establish such tools appears. In creating of such tools following key areas can be identified (and partially are reflected in our research): (1) determination of the optimal set of metadata, which would take into account the objectives of learning, the goals of separate courses, the content of learning objects, knowledge and experience of each student; (2) determination of the optimal set and methods taking into account of students feedback while they work with learning objects. Another trend is to take into account the features of not only the individual student, but of the educational communities.

Sumy State University carries our development activities to create software tools to build and manage individual learning paths of students. Work is carried out based on the integration of these three areas. Nowadays the solutions received are different from the known analogues considering an expanded set of information about the features of a particular student's learning activities (19 indicators are analysed, including indicators of progress such as the level of knowledge, and student individual features, for example, the degree of language skills, math learning bias or inclination to use video content for training, etc.). The corresponding software solutions are being tested in an SSU e-learning environment.

\section{References}

Berghel, H. (1997). Cyberspace 2000: Dealing with information overload. Communications of the ACM, 40(2), 19-24.

Brusilovsky, P., Millán, E. (2007). User models for adaptive hypermedia and adaptive educational systems. In: Brusilovsky, P., Kobsa, A., Neidl, W. (Eds.), The Adaptive Web: Methods and Strategies of Web Personalization. LNCS, Vol. 4321. Berlin, Heidelberg, New York, Springer-Verlag, 3-53. 
Dovbysh, A.S. et al. (2011). Information-extreme algorithm for recognizing current distribution maps in magnetocardiography. Journal of Automation and Information Sciences, 43(2), 63-70.

Farrel, R., et al. (2003). Learner-driven assembly of web-based courseware. In: Proceedings of E-Learn, Phoenix AZ.

Gagarin, A., Tytenko S. (2007). Complex model of educational hypermedia environment for ongoing learning. In: В.А. Гребенюка, Др. Киншука, В.В. Семенца (ред.) Образование и виртуальность2007. Сборник научных трудов 11-й Международной конференции Украинской ассоциачии дистаниионного образования. Харьков-Ялта, УАДО, 140-145.

Hiroyuki, M. et al. (2002). An adaptive web-based learning system with a free-hyperlink environment. In: Proceedings of Workshop of Adaptive Systems for Web-based Education 2002 (WASWE2002). Malaga, Spain, 13-26.

HI-Tech in Education: Sumy State University Experience. http: / / fpkpi.sumdu.edu.ua/en/.

Jones, M.T. (2008). Artificial Intelligence: A Systems Approach. Jones\& Bartlett Learning.

Knuth, D.E. (2005). Art of Computer Programming, Vol. 3. Addison-Wesley.

Lubchack, V., Kuzikov, B., Kirichenko, K. (2010). Using semantic web and covering context by test for course formal testing. In: 8th Int. Conference on Emerging eLearning Technologies and Applications. The High Tatras, Slovakia.

Lyubchak, V.A., Kyrychenko, K.I. (2010). System of e-learning management at Sumy State University. In: Troitzsch, K.G., Chernyshenko, S.V., Lyubchak, V.A., Kyrychenko, K.I., Wodecki, A. (Eds.) Proceedings of the 1-st Workshop of the Training Programme for Developers of Educational Courses. Lublin, Poland. Sumy Publishing office of SSU, 51-57.

MIT OCW Introduction to Algorithms (SMA 5503) Lecture 4: Quicksort, Randomized Algorithms. http: / / ocw.mit.edu/courses/electrical-engineering-and-computerscience/6-046j-introduction-to-algorithms-sma-5503-fall-2005/videolectures/lecture-4-quicksort-randomized-algorithms.

OERcommons.org Find Free-to-Use Teaching and Learning Content from Around the World . http: / / www . oercommons . org

Paul, D.B., David, S. (2012). A fully generic approach for realizing the adaptive web-SOFSEM 2012. Theory and Practice of Computer Sience.

Pegler, C. (2012). OER: opening doors and breaching boundaries. Enhancing Learning in the Social Sciences, 4(1), 2012.

Thomas, H.C., Charles, E.L. et al. (2001). Introduction To Algorithms. MIT Press.

UNESCO СНГ на пути к открытым образовательныцм ресурсам (2011). http://ru.iite.unesco.org/publications/3214683 (in Russian).

Vasiljev, A.V., Lubchak, V.O. (2008). Телекомуникацийне информацийно-освитны середовище Сумського державного университету. In: Мижнародна науково-практична конференция енавчання у вищий школи й перспективи (INCEL-08). Odesa, CD-ROM ISBN 978-966-593-624-4.

Kuzikov, B.O. (2011). Адаптивне керування навчальною дияльнистю на основи прецедентив. Висник НТУ ХПИ, 35, 101-110 (in Ukrainian).

Kureichik, V.M., Pisarenko, V.I., Kravchenko, J.A. (2008). Адаптивная модель организации малых учебных групп в интеллектуальных автоматизированных образовательных системах. Дистанционное и виртуальное обучение, 11, 44-54 (in Russian). 
V. Lubchak - vice-rector of Sumy State University, $\mathrm{PhD}$ in physic-math. sciences. Sphere of concern: introduction of modern electronic education technologies into academic process, IT support of university administrative activity. Coordinator on behalf of SSU of several international projects funded by EU and covering such fields as life-long learning, e-learning and improvement of the distance learning systems. Areas of scientific interest: ICT, information management, IT applications for academic activity.

O. Kupenko - dean Faculty of Skills Upgrading and Pedagogical Innovations, PhD of pedagogical studies. Areas of scientific interest: the theory and methods of educational administration, lifelong learning, skills upgrading of pedagogical staff, information technologies in education.

B. Kuzikov received his bachelor degree in 2006 by the Sumy State University. Currently he is a PhD student at the Sumy State University, Faculty of Electronic and Information Technology, head of E-Learning System Laboratory. His works in the area of user modelling and personalization.

\title{
Dinaminis individualizuoto mokymosi kelio parinkimo metodas
}

\author{
Vladimir LUBCHAK, Olena KUPENKO, Borys KUZIKOV
}

Studentu heterogeniškumą elektroninio mokymosi aplinkoje apibrež̌ia skirtingi ju gebejjimai, žinių lygis ir poreikiai. Pagrindinis Sumų valstybinio universiteto (Sumy State University) igyvendinamo elektroninio mokymosi projekto tikslas yra atsižvelgiant ị minètus individualius studentu poreikius sudaryti individualų mokymosi kelią. Straipsnyje pateikiama esama elektroninio mokymosi situacija Ukrainoje, aprašoma šiuolaikiniu adaptyviujų mokymosi sistemu plètoté ir pristatomi Sumų universiteto atlikto tyrimo rezultatai. Tyrimas rodo, kad dabartiniai sprendimai skiriasi nuo ankstesniujų dèl platesnès informacijos apie konkretaus studento mokymosi veiklas (buvo analizuota 19 indikatorių). Atitinkami programinès įrangos sprendimai buvo ištestuoti Sumu universiteto elektroninio mokymosi aplinkoje. 